\title{
THE LIFE AND TIMES OF
}

\section{CRISTÓBAL DE MOLINA}

CA. 1529 Cristóbal de Molina is born in Baeza, Spain.

1556 Molina arrives in Cuzco.

1558-1560 Polo de Ondegardo's first term as chief magistrate of Cuzco

1564 Luis de Olivera, while serving as the priest of Parinacocha, notes an increase in the idolatrous activities of his parishioners. This movement becomes known as the Taqui Onqoy.

1565 Molina is appointed as the priest in the Hospital for the Natives of Our Lady of Succor in Cuzco. Over time, he was also named preacher general of the Cuzco parishes and visitor general for parts of the Cuzco bishopric.

1568-1571+ Cristóbal de Albornoz leads a series of campaigns in the Peruvian highlands to identify and destroy native shrines and to punish the individuals and communities who worshipped them. Both Molina and Olivera are also active in the anti-idolatry campaigns.

1571 Viceroy Francisco de Toledo meets Albornoz in the Huamanga area.

1571-1572 Toledo is in Cuzco. He orders a series of interviews to be conducted concerning the his- 
tory of the Incas. Molina writes his now-lost work History of the Incas at the request of the viceroy.

1 MARCH 1572 Pedro Sarmiento de Gamboa finishes his History of the Incas while in Cuzco.

24 SEPTEMber 1572 The last independent royal Inca, Tupac

Amaru, is executed in Cuzco. Molina is one of several priests who accompany him during his final day.

4 JULY 1573 Sebastián de Lartaún is installed as the third bishop of Cuzco. Soon afterward, Molina provides the bishop with a document titled Account of the Huacas as well as a copy of his own History of the Incas.

1573/1575? Molina writes his Account of the Fables and Rites of the Incas at the request of Bishop Lartaún.

6 NOVember 1575 While in Arequipa, Toledo orders a salary adjustment for Molina. In his letter, Toledo notes that Molina had collected information on the rites and ceremonies of the Incas.

14 JANUARY 1577 Molina testifies in Cuzco on behalf of Albornoz.

2 APRIL 1582 Molina is interviewed in Cuzco concerning the laws of the Incas.

1582-1583 The Third Lima Provincial Council. Molina attends, but the exact dates are not known. He leaves Cuzco in late May or early June, carrying a letter from the indigenous leaders of Cuzco requesting tax-exempt status. He leaves early, and on his return, Molina meets Albornoz, who was traveling to Lima to attend the council. 
9 OCTOBER 1583 Lartaún dies in Lima while attending the Third Lima Provincial Council.

28 MARCH 1584 Molina testifies in Cuzco for the second time on behalf of Albornoz.

29 MAY 1585 Molina dies in Cuzco, at approximately fiftysix years of age.

1586 Miguel Cabello Valboa finishes his Miscelánea antártica. He notes that he used Molina's History of the Incas while writing the work.

1647 Francisco de Ávila dies. In his enormous library is the only surviving copy of Molina's Account of the Fables and Rites of the Incas.

1649 Dean Vasco de Contreras y Valverde finishes his work Account of the City of Cuzco. He notes that he used Molina's History of the Incas while writing the work.

1653 Bernabé Cobo finishes his work History of the New World. He notes that he used Molina's Account of the Fables and Rites of the Incas. Cobo's copy of the account is now lost.

1873 Avila's copy of Molina's Account of the Fables and Rites of the Incas is found in the National Library in Madrid. Clements Markham publishes an English translation.

1913 The first Spanish edition of Molina's account is published in Chile. Numerous other editions follow. 